\title{
WEBGIS BASED POVERTY LEVEL ANALYSIS (CASE STUDY OF WONOSARI SUB-DISTRICT BOALEMO REGENCY)
}

\author{
Irwan Muis ${ }^{\mathrm{a}}$, Sunarty S. Eraku ${ }^{\mathrm{a}}$, Syahrizal Koem ${ }^{\mathrm{a}}$ \\ ${ }^{a}$ Geography Education Study Program, Department of Earth Science and Technology, Faculty of Mathematics and Natural \\ Sciences, Universitas Negeri Gorontalo, 96128 Indonesia
}

\section{ARTICLE INFO}

\section{Article history:}

Received: 29 May 2019

Accepted: 18 July 2019

Available Online: 24 July 2019

\section{Keywords:}

Households; Poverty; WebGIS

\section{Corresponding author:}

Irwan Muis

Geography Education Study Program,

Department of Earth Science and

Technology, Faculty of Mathematics and Natural Sciences, Universitas

Negeri Gorontalo, 96128 Indonesia

Email: irwanmuis97@gmail.com

\begin{abstract}
Information on household poverty level in Wonosari Sub-district area is still very difficult to access by all parties. Therefore, this study aims to analyze poverty level and map of the spatial distribution of webGIS-based poor households in the site area. In determining the number of samples, descriptive statistical analysis techniques focused on assessing and describing the poverty level of each household. GIS analysis used GIS Application 2.18 to map the spatial distribution of poor households and regional poverty levels. GIS Application has been equipped with 2 web tools that are able to display webGIS-based maps. The results shows that the poverty level of households is in the poor category with a percentage of $72 \%$ of households, $14 \%$ of households are in the extremely poor category and $14 \%$ are in the fairly poor category. and 1 village is in a fairly poor category. This is a village that was built with a view that can be accessed by various PCs, laptops and android media so that the maps information from an analysis of household poverty levels and the spatial distribution of poor households can be accessed on the webGIS that has been built.
\end{abstract}

Copyright $(\mathrm{C} 2019$ JGeosREV-UNG This open access article is distributed under a Creative Commons Attribution (CC-BY) 4.0 International license

\section{Introduction}

The problem of poverty has always been an issue and discussion for people from all walks of life. The state of the country's economy which has not improved, has an impact on the problem of poverty which requires more serious attention. In this case the government and the community have the obligation and responsibility to overcome the poverty that occurs in the entire territory of the Unitary State of the Republic of Indonesia. The household poverty perspective, which is found in several provinces, districts, sub-districts and villages in Indonesia, is one of the benchmarks in measuring household welfare. the problem of poverty in Indonesia has been described in the annual report of the world bank that Indonesia is in the order of nine countries with the highest percentage of poor people in the world (World Bank, 2015). The inability of someone or a group of people to economically meet the average standard of living of a community in an area will have an impact on increasing poverty. This condition of incompetence, characterized by low-income capacity in meeting all basic needs approaches (BPS, 2018).

Based on data at the Boalemo Regency Central Bureau of Statistics in 2018, it shows that the increase in the number of poor people in Boalemo Regency from 2014 - 2017 continues to experience tidal dynamics. This is shown by the percentage of poor people in Boalemo Regency from 2014 as many as $20.79 \%, 21.67 \%$ in $2015,21.11 \%$ in 2016 , and $21.85 \%$ in 2017 . Wonosari Subdistrict is one of the sub-districts located in the Boalemo District, with astronomical location at $00^{\circ} 37$ ' $144^{\prime \prime} 00^{\circ} 5$ ' $33^{\prime}$ ' $L U$ and $122^{\circ} 17^{\prime} 16^{\prime}$ ' $122^{\circ} 30^{\prime} 16^{\prime}$ 'BT. The area of Wonosari District is $\pm 229.10 \mathrm{~km} 2$ with a population of 26,422 people in 2017. The percentage of poor households in Wonosari Subdistrict is the second largest after Paguyaman Subdistrict with a number of poor households totaling 2,408 households. This number 
is based on data from recipients of welfare family rice assistance (Rastra). The selection of the Wonosari Subdistrict as a research location is based on areas with abundant natural resource potential both in agriculture and industry and has a fairly good landscape for the agricultural process, but does not guarantee and illustrate the improvement of community welfare (Dinas Sosial, 2018 ).

Areas with good natural resource potential, in harmony, illustrate a fairly good increase in household welfare, so that over time the percentage of poor households will continue to decrease. Besides that, the availability of information on household poverty levels and information on the identity of poor households in Wonosari Subdistrict is very difficult to obtain, so a spatial-based analysis related to household welfare level is highly needed to measure the percentage of household welfare in each village area Wonosari Sub-District. In this study, the criteria used as a benchmark in analyzing household poverty levels are 14 criteria issued by the Central Bureau of Statistics (1) Floor area of residence $<8 \mathrm{~m} 2$ per person, (2) Type of house / bamboo flooring / cheap wood, (3) Types of walls made of bamboo, thatch, low quality wood, walls without plaster, (4) Do not have MCK (toilet and bathroom) facilities or together with other households, (5) Do not use electricity as a lighting source, (6 ) Source of drinking water comes from wells, unprotected springs, rivers or rainwater, (7) Daily cooking fuels are wood, charcoal, and kerosene, (8) Only consume meat, milk, chicken once a week, (9) Only able to buy a new set of clothes in a year, (10) Only able to eat as many as one or twice in a day, (11) Unable to pay for medical expenses at the Puskesmas (resident medical aid center), and Polyclinic. (12) Source of income for the head of the farming household with land area of $500 \mathrm{~m} 2$, fishermen, farm laborers, construction workers, plantation workers and / or other jobs with income below Rp. 600,000 /month, (13) Education level of the head of the household, not attending school, not completing elementary school, graduated from elementary school, (14) Having no savings, items that are easily sold at least Rp. 500,000 such as gold, credit or non-credit motorbikes, livestock, ships / boats, or other capital goods (BPS, 2018).

In several regions in Indonesia, many information systems have been developed regarding the level of household poverty and the distribution of poor web-based households. The household poverty level needs to be analyzed along with other factors that influence the household poverty level. Spatial automatic correlation is a spatial statistical analysis tool that explores spatial dependence and helps detect spatial patterns of these phenomena (Lee \& Wong, 2001). Research on the development of information systems in the distribution of poor households has been carried out in the area of Puhun Tembok, Bukittinggi. The location of households is scattered and the spatial information of every poor household that is less accurate has an impact on the poverty alleviation program that is not on target. Therefore an information system was built based on location information for each poor household based on the web-based Puhun Tembok Village. Software development used was the waterfall method (Fithriyyah et al., 2016). Gibranda et al., (2018) developed webgis for data analysis and modeling using spatial regression techniques and R-shiny web framework. Regression analysis is a method commonly used to see the relationship of a variable with other variables, see geographical conditions, regional potential, socio-cultural conditions and other things that are behind it, so that spatial heterogeneity arises. Previous research has developed an information system that uses secondary data, with various web development models, so that information on poverty levels and distribution of poor households can be easily accessed. Webgis is a means of displaying spatial information by utilizing developing website technology today, a combination of website technology and GIS is able to present an information system that is more dynamic in terms of development, to user access to the system. The design and creation strategy used will produce a GIS-based information system that has certain advantages. In addition to carrying out design and creation strategies, research also makes information systems using the waterfall design method, so that information systems are made in stages.

This research was carried out by taking field data, using multistage random sampling, surveys and interviews. Research support is based on direct data collection so that the resulting data is accurate and renewable. The design of web systems is designed using geographic information system software so that the display is more attractive because the information that will be displayed on the web is focused on maps of poverty levels and spatial distribution of poor households. Spatial analysis of the level of poverty of webGIS-based households needs to be conducted considering that information on the level of poverty and spatial distribution of poor households in Wonosari Subdistrict is still very difficult to obtain, due to the unavailability of information systems that specifically provide information on poverty levels and spatial distribution data of poor household that are easily obtained and accessed by any party, for the development and poverty alleviation in Wonosari Subdistrict. The availability of thematic 
information on poverty levels and the spatial distribution of webgis-based poor households, can help related parties in planning the development of the sub-district in the future.

The purpose of this study is to analyze poverty levels and map the spatial distribution of poor, webgis-based households that are easily accessible and accessible to all parties. The construction of a geographic reference information system, regarding mapping poverty levels and spatial distribution of poor households to the sub-district level, was carried out so that information on household poverty levels and spatial distribution of poor households can be easily seen and accessed to support national development and poverty alleviation programs. Maps of poverty and the spatial distribution of webbased poor households can be used by the central, regional and community governments to plan a more comprehensive national development system, effective level of information at village level that is easily accessible and thematic information presented is accurate and renewable.

\section{Methodology}

\subsection{General Description of Research Site}

The study was conducted in Wonosari Sub-District, Boalemo Regency. Wonosari Subdistrict is one of 7 sub-districts located in the Boalemo Regency area, which has 14 villages with a total sub-district area of $229.10 \mathrm{~km} 2$ and a population of 26,422 people in 2017. Wonosari Subdistrict is astronomically located at 003714 "55 " 33 'LU and 1220 17' 16'- 122030 16' BT. Wonosari Subdistrict shares its border with Asparaga Subdistrict to the north, Paguyaman Subdistrict to the south and east, Dulupi Subdistrict to the west (Figure 1). The demographics of the Wonosari Subdistrict population is dominated by Gorontalo residents and a small part of transmigrants who come from several other provinces such as Java, NTB, Bali, and North Sulaw esi. Most of the people in this subdistrict work as farmers, but few of them work as traders, entrepreneurs, and government employees. The profession as a farmer is a profession chosen by the Wonosari Sub-District community. The profession as a farmer surely have an impact on people's income. There are around $86 \%$ of total households earn an average of Rp. $<600,000$ per month. Only about $12 \%$ of total households earn on average Rp. $>600,000$ per month.
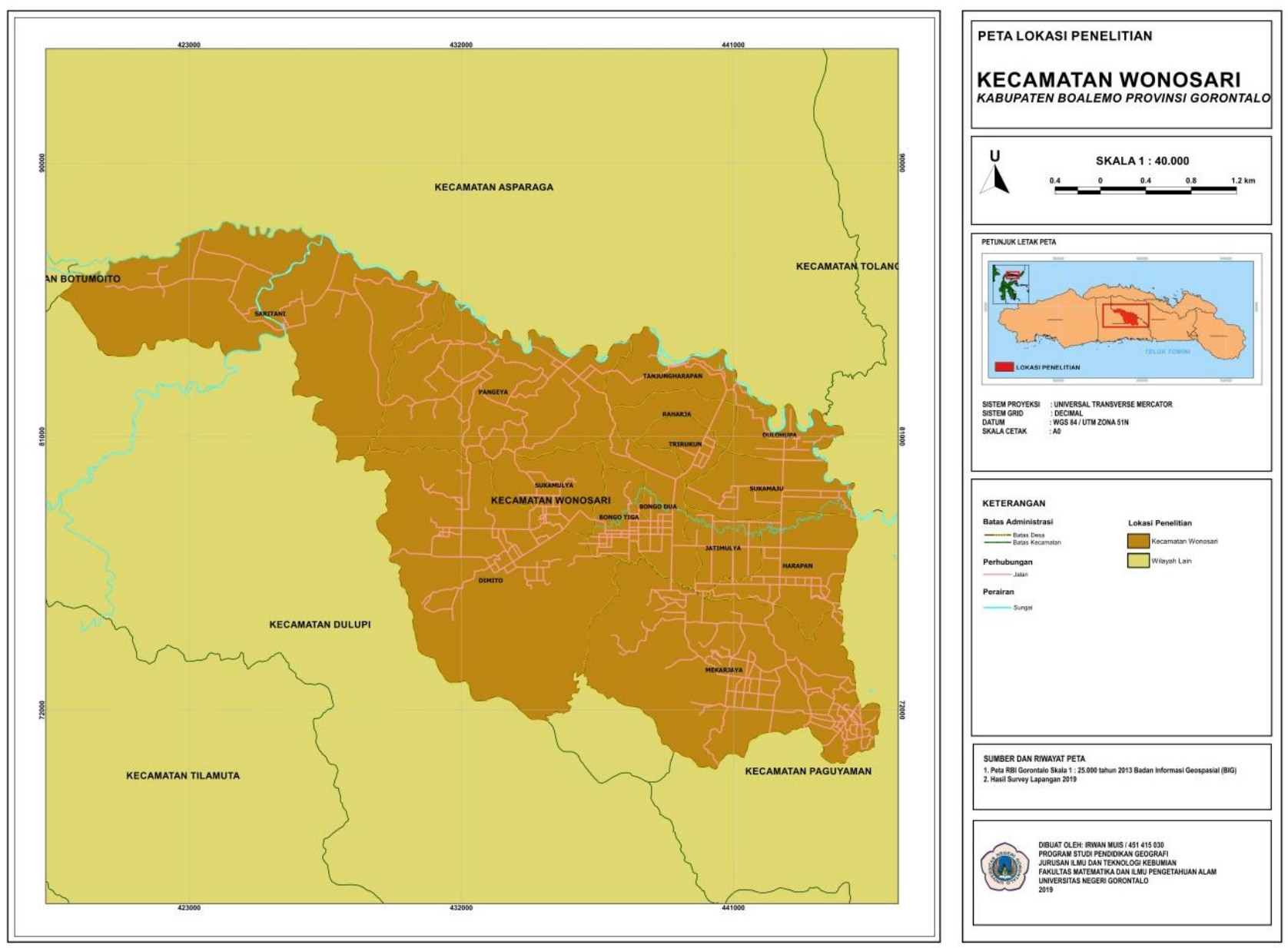

Figure 1. Map of research site 
Table 1. Data and their sources

\begin{tabular}{lllll}
\hline No & Data & Type & Source & Purpose \\
\hline 1 & $\begin{array}{l}\text { Coordinates of poor } \\
\text { households }\end{array}$ & Primary & GPS & $\begin{array}{l}\text { Find out the spatial } \\
\text { location of poor } \\
\text { households }\end{array}$ \\
2 & $\begin{array}{l}\text { Identities of poor } \\
\text { households }\end{array}$ & Secondary & Village Office & $\begin{array}{l}\text { Find out the identity of } \\
\text { households that were } \\
\text { interviewed }\end{array}$ \\
3 & Poverty criteria & Primary & Questionnaire & $\begin{array}{l}\text { Household poverty } \\
\text { analysis } \\
\text { Borders of research site }\end{array}$ \\
\hline
\end{tabular}

\subsection{Tools and Materials}

Tools which was used in the research are Garmin Oregon 550's global positioning system (GPS), questionnaire, a computer that has been equipped with GIS APPLICATION 2.18, cameras and writing instruments. The materi als used were, Gorontalo RBI scale 1 : 50000 (2013 revision) of Geospatial Information Agency, data on the identity of poor households. Data and their sources are presented in Table 1.

\subsection{Data Collection}

The method used are multistage random sampling, surveys, and interviews. Multistage random sampling aims to make the sampling of poor households evenly distributed. The determination of the number of samples to the population is carried out with an accuracy level of $95 \%$ (5\% error margin). The data used in this study consists of primary data and secondary data. Primary data in the form of coordinates of the location of poor households obtained by conducting surveys and poverty criteria data which was obtained by conducting interviews using questionnaires. Secondary data (administrative boundary) was obtained by downloading thematic maps of village and sub-district administrative boundaries that is available on http://tanahair.indonesia.go.id/portal-web which is the official website of the Geospatial Information Agency. The types and techniques of data collection are presented in Table 2.

\subsection{Data Processing and Data Analysis}

Analysis technique descriptive quantitative is used for group data or change raw data like answers from questionnaire which will be processed later become group data. For change the primary data in frequency distribution table form is necessary note the steps, for example determine the number of interval classes which will be made using amount of data (Dimitra \& Yuliastuti, 2012). Descriptive processing and statistical analysis of household poverty data, carried out using the Sturges equation to classify household poverty levels. Descriptive statistical analysis using the sturges equation, allows data to be processed to use frequency distribution tables with the results of analysis that can describe the correctness of the data in accordance with what is obtained without making general conclusions. The Sturges rule is presented in the following equation:

$k=1+3.3 \log n$

where: $(k)$ number of classes, $(n)$ number of observations

$r=$ maximum value - minimum value

where: (r) difference between largest and smallest data

$\mathrm{i}=$ range: class

where: (i) class intervals

Table 2. Types and techniques of data collection

\begin{tabular}{lll}
\hline No & Types of Data & Technique \\
\hline 1 & Coordinates of poor households & Taking coordinates using GPS in the field survey. \\
2 & Poverty criteria & Conducting direct interviews using a questionnaire. \\
3 & Administrative border & $\begin{array}{l}\text { Downloading RBI Map of Gorontalo in 2013 Badan } \\
\text { Informasi Geospasial (BIG). }\end{array}$ \\
4 & Poor households identities & $\begin{array}{l}\text { Village office } \\
\text { Conducting survey and capturing a picture of the } \\
\text { physical condition of the household }\end{array}$ \\
\hline
\end{tabular}


Table 3. Number of poverty classes

\begin{tabular}{lll}
\hline Classes & Intervals & Class Categories \\
\hline 1 & $1-4$ & Sufficient \\
2 & $5-8$ & Quite Poor \\
3 & $9-12$ & Poor \\
4 & $13-14$ & Very Poor \\
\hline
\end{tabular}

Thus the data from interview can be tabulated and then made a frequency distribution to determine the poverty class $(\mathrm{k})$, range $(\mathrm{r})$ and class interval (i). the number of poverty classes $(\mathrm{k})$ is obtained from the sum of $1+3.3 \log 14$ where number 14 is the number of observation criteria, so that 4 poverty classes are obtained. The range value (r) is obtained from the calculation of the value of 14-1 (observation criteria) so that the value of the range $(r)=13$ is obtained. Furthermore, the class interval value (i) is obtained from the division of values 13: 4 (13 range values and 4 number of classes) so that the value of the class interval (i) $=3$ is obtained. Then a table of frequency distribution was made with the number of 4 poverty classes namely, sufficient class, quite poor, poor and very poor. The poverty class (k) is presented in Table 3.

Descriptive statistical analysis is carried out to describe, visualize, and give value that can facilitate GIS process. The coordinate data of poor households and administrative boundaries are then spatially analyzed, so as to produce new information in the form of thematic maps of poverty levels and distribution of poor households that are geographically referenced which can be displayed online on the webgis has been developed.

\subsection{Webgis Publication Stage}

The construction of webGIS with the waterfall model, emphasizes the development of systems between one phase to another phase in sequence. There are 5 (five) stages in Waterfall medol which are carried out, namely, designing system requirements (qgis2web plugin), webGIS integration, hosting, webGIS testing and implementation. The stages in the process of building a webGIS information system are presented in Figure 2 waterfall of webGIS building.

The household poverty level map that has been created would be displayed online to provide easy access to all parties. Geographical information system applications are equipped with tools that are capable of displaying maps online. Thus the user would be easier in the process of creating webgis. After webgis has been completed, it would be integrated into a web server and hosting to give all parties easy access to this map. Webgis testing was conducted to find out the weaknesses of webgis that has

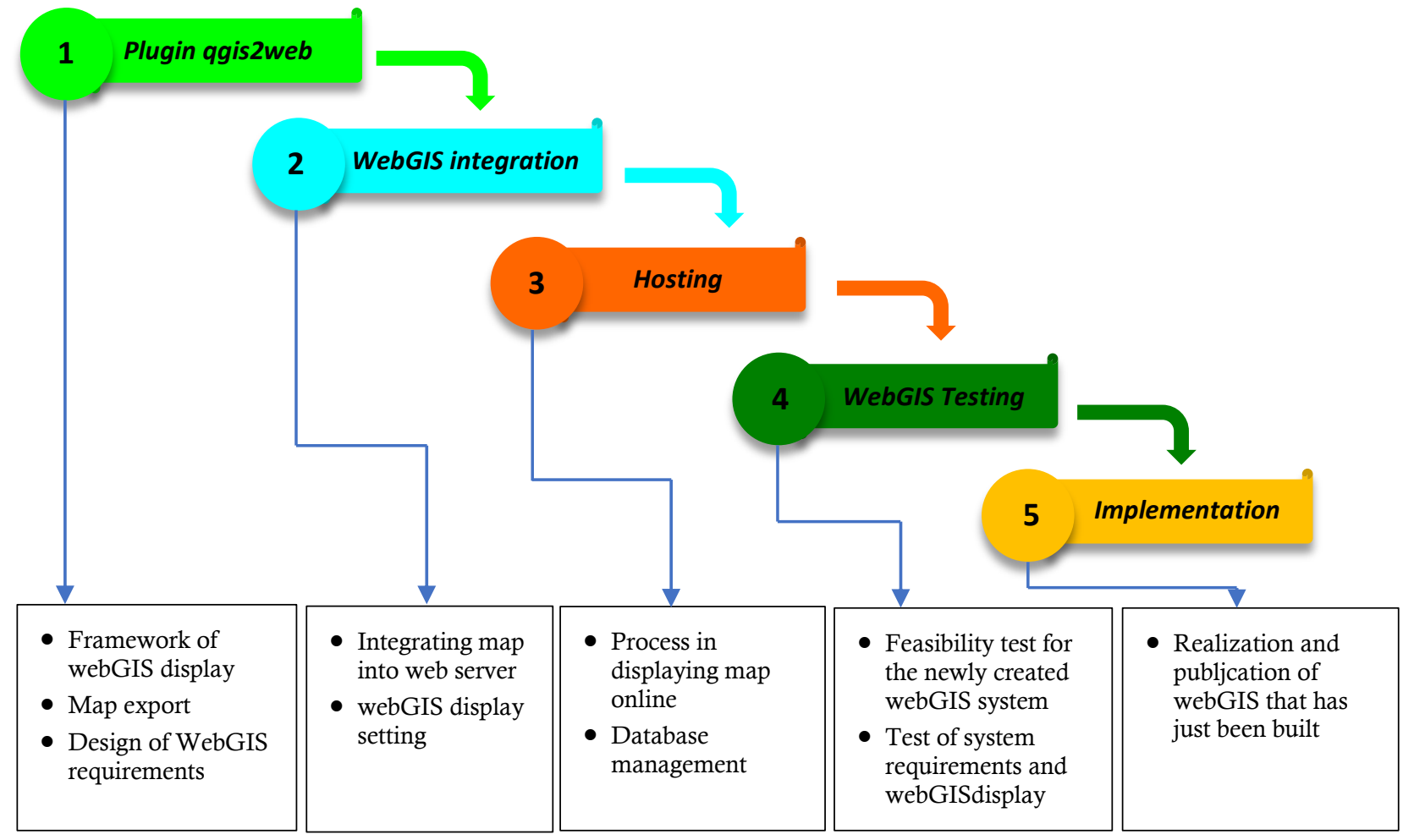

Figure 2. The waterfall of building webGIS 


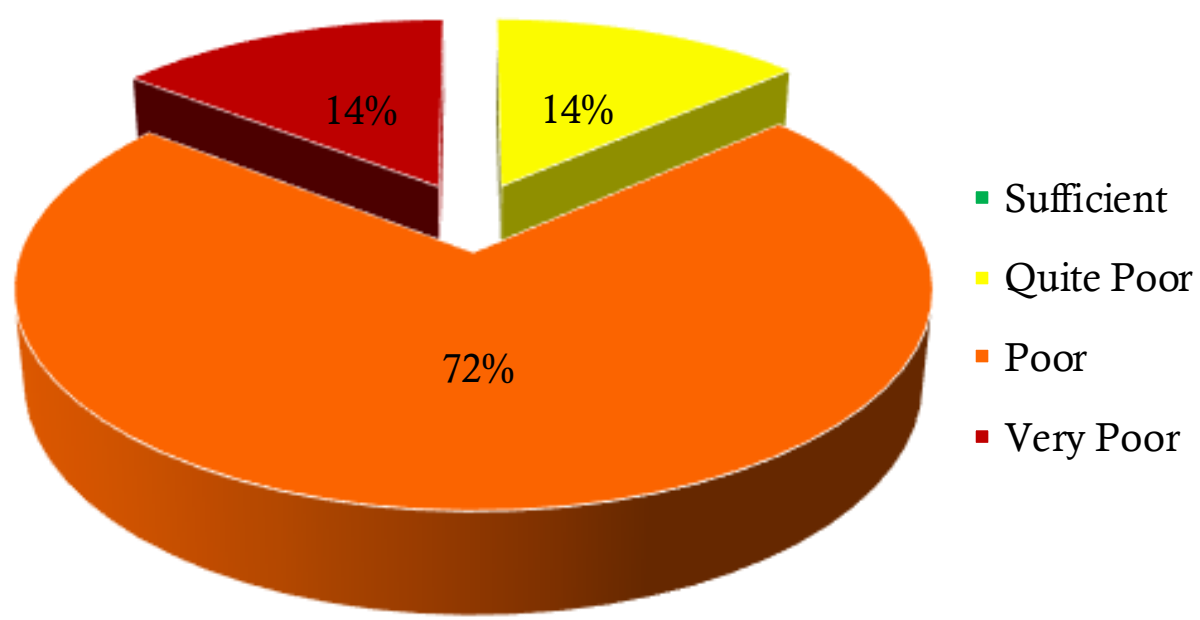

Figure 3. Percentage of poor households

just been created, web testing was conducted by doing a number of testing support display on PC, laptop, android and other media. This test aims to let users know the weaknesses and strengths of webgis for further improvement so that the webgis can perform as expected.

\section{Result and Discussion}

Demographics of respondents consists of $44 \%$ were in the age of $31-50$ years, $33 \%$ were in the age of $50-70$ years, $15 \%$ were in the age of $17-30$ year age range and around $8 \%$ were in the age of $>70$ years old. The level of education is one of the criteria of poverty. From 304 respondents, there were 236 respondents with elementary school education, 47 respondents did not finished elementary school (SD), 14 respondents graduated from junior high school (SMP), 6 respondents graduated from high school, and 1 respondent with an undergraduate education. In terms of income, there were $86 \%$ of respondents who earned Rp. $<600,000$ per month, $12 \%$ who earned Rp. $>600,000$ per month and $2 \%$ who earned Rp. 300,000.

\subsection{Household Poverty Level}

In the process of analyzing poverty levels, there are several criteria that are often used, one of which is 14 criteria used by the central statistical body to measure household welfare with assumptions that are fulfilled. 7 criteria are met, households are in the poor class, 9 criteria are met. being poor and 14 criteria fulfilled, the household is in a very poor class (BPS, 2018). 14 This criterion is a benchmark in analyzing poverty levels, it is expected that these 14 criteria can describe the condition of the community's poverty level. In the division of poverty classes do not use assumptions but using the Sturges equation as described above. To carry out the poverty level analysis, researchers divided the class into 4 types of classes (sufficient, quite poor, poor and very poor).

Poverty level mapping is done to integrate two types of data in GIS, namely spatial data and attribute data (conventional) with the aim of research innovation in the development of poverty alleviation policies. The development of spatial databases related to poverty on a detailed scale can provide prospective opportunities and challenges in order to encourage the birth of policies, plans for poverty reduction programs (Harmes et al., 2017). A diverse analysis of techniques combined with GIS analysis can provide a better range of opportunities and improve the quality of poverty alleviation programs and program implementation. In this study the data used were primary data obtained directly by conducting surveys and interviews using questionnaires, so that the data to be processed is data that has a geographical reference in the form of identity, poverty criteria and coordinates of poorly renewed households.

The number of poor households based on the level of poverty illustrates the poverty condition of the Wonosari Subdistrict in the poor class with a percentage of around $72 \%$ of the total 304 household respondents, around $14 \%$ of the household respondents are in the very poor class and $14 \%$ of the household respondents are in pretty poor class. This number is based on the sample taken as many as 304 poor households outt of a total population of 2408 poor households in Wonosari District. The percentage of the number of poor households is presented in Figure 3.

Each village in Wonosari Subdistrict has an area, village potential, community work and different numbers of poor populations and households. The analysis of regional poverty level was conducted by 
Table 4. Poverty level

\begin{tabular}{llll}
\hline No & Village & Class Categories & Poverty Value \\
\hline 1 & Bongo II & Poor & 10 \\
2 & Trirukun & Poor & 9 \\
3 & Tanjung Harapan & Poor & 10 \\
4 & Bongo III & Poor & 9 \\
5 & Dulohupa & Poor & 10 \\
6 & Jati Mulya & Poor & 10 \\
7 & Raharja & Poor & 9 \\
8 & Dimito & Poor & 11 \\
9 & Mekar Jaya & Poor & 10 \\
10 & Suka Mulya & Poor & 10 \\
11 & Suka Maju & Poor & 9 \\
12 & Harapan & Quite Poor & 8 \\
13 & Pangeya & Poor & 11 \\
14 & Saritani & Poor & 12 \\
\hline
\end{tabular}

calculating the average value of the poverty level for the existing sample per village area, the results of calculating the average poverty value for the sample per village region can describe the poverty level of the village area. From 14 villages in Wonosari Subdistrict, 13 villages were in the poor category and 1 village was in the fairly poor category. Regional poverty levels are presented in Table 4.

\subsection{Map of Poor Household Distribution and Regional Poverty}

Map of the household poverty level can describe the welfare condition of each household in the Wonosari Subdistrict area. Further elaboration of statistical data using the GIS Aplication 2.18 produces new information in the form of thematic maps of the distribution of poor households in Wonosari District. The difference in the poverty class can be seen in the color difference of each household. Green for sufficient class, yellow for quite poor class, orange for poor class and red for very poor class. In general, the poverty level of each household in the Wonosari Subdistrict area is in the
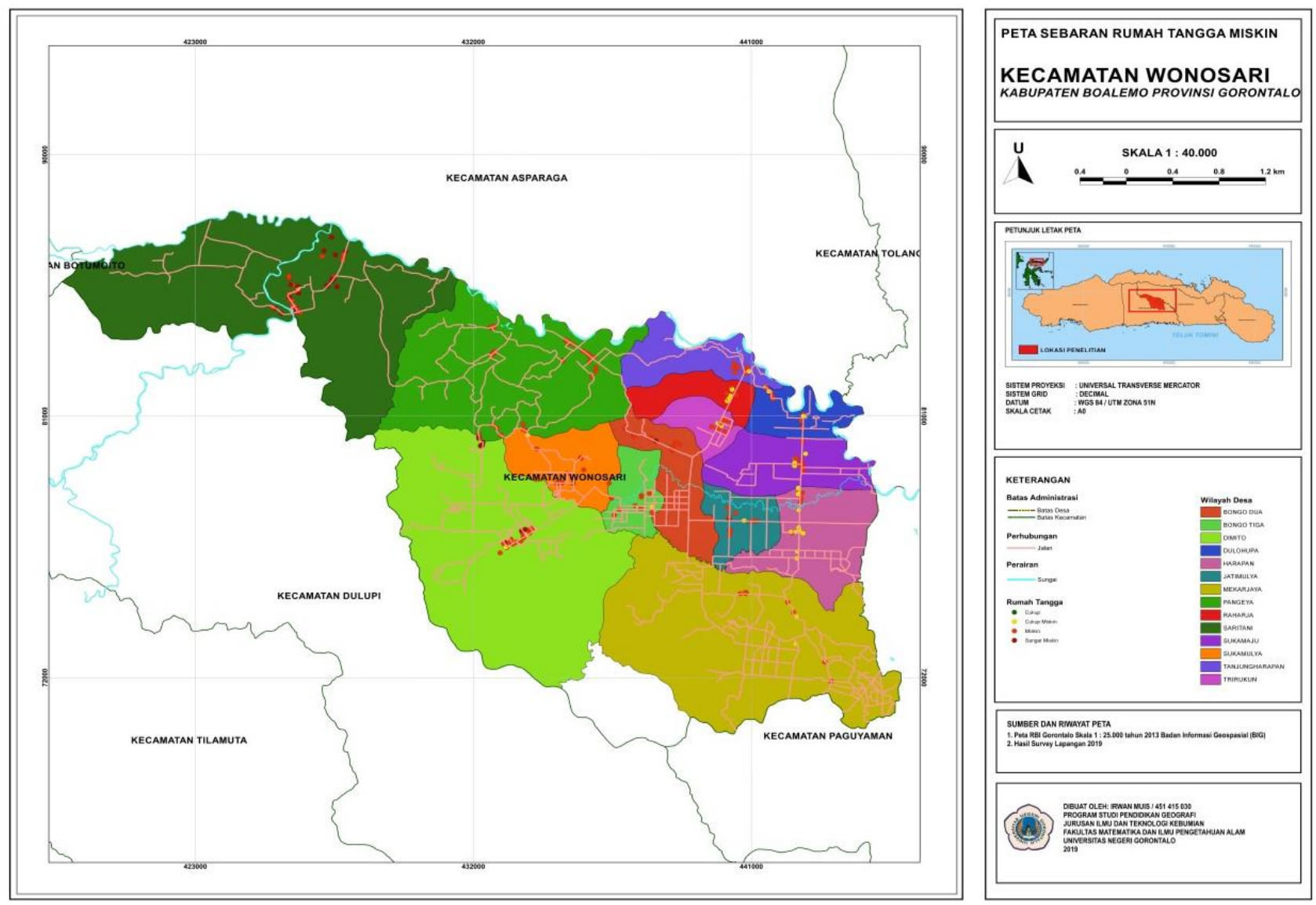

Figure 4. Poor households distribution map 

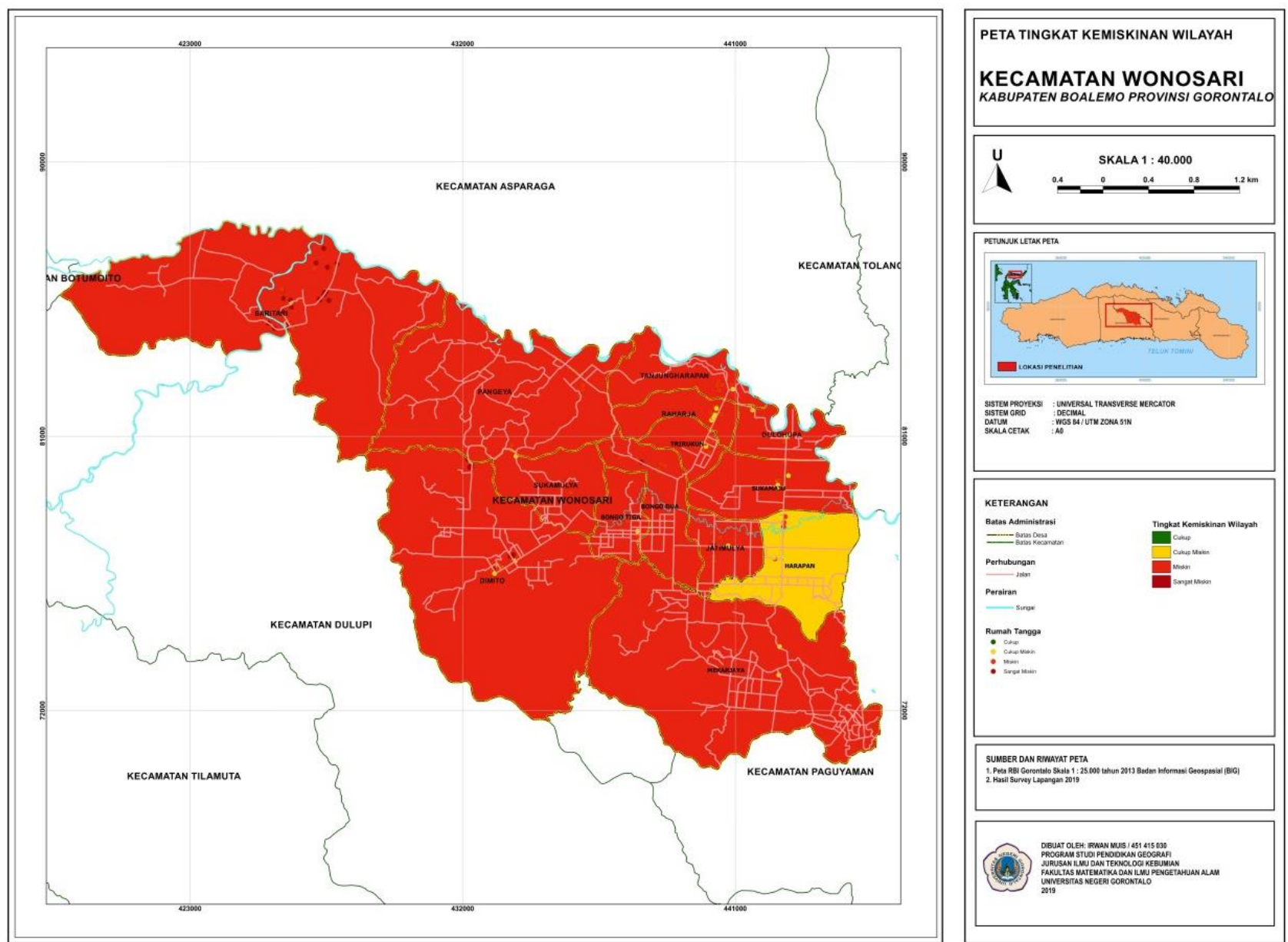

Figure 5. Regional poverty level map

quite poor, poor and very poor class. Map of the poverty level and spatial distribution of poor households are presented in Figure 4.

After analyzing the level of poverty on a household scale, then the poverty level analysis is carried out in each village using statistical data from the result of survey and interviews. The process of processing and analysis of poverty levels in the village is portrayed with color difference in each village. This poverty class was created using Sturges equation. In general, the poverty level in each village in Wonosari Subdistrict is in a poor class (13 villages) and only 1 village that is categorized in a quite poor class. The village which is categorized in a quite poor class is Harapan Village, this village is the center of Wonosari Subdistrict with high economic activity both in the people's market and in the shops that can be found in that village. Map of poverty level is presented in Figure 5.

\subsection{WebGIS Integration}

According to Fithriyyah et al (2016) the development of information systems in the distribution of poor households and spatial information on the location of poor households that are less accurate will have an impact on poverty alleviation programs that are not right on target so that web-based information systems are built with the development of the waterfall method software. In this study, the mapping process uses the application of Geographic Information Systems (GIS) so that the strength of the GIS (spatial) elements in this study is stronger. Online or ordinary mapping, called webgis, can display the map, so that it is easily accessible to all parties. thus the future assistance program can be channeled on target, so that it can reduce poverty in the future. The GIS application used is equipped with the qgis2web plugin, so that in displaying the poverty level map online, researchers use the qgis 2 web plugin. In order for the qgis 2 web plugin to be used, it is first activated in the application, by clicking the plugin menu on the application and looking for qgis 2 web then installing the qgis 2 web plugin. After the household poverty level map is ready to be displayed online, then click the web menu in the GIS application and select qgis2web. The map platform used is an open layer so that it is free. After the display is set as desired, click export then the household poverty level map will automatically 


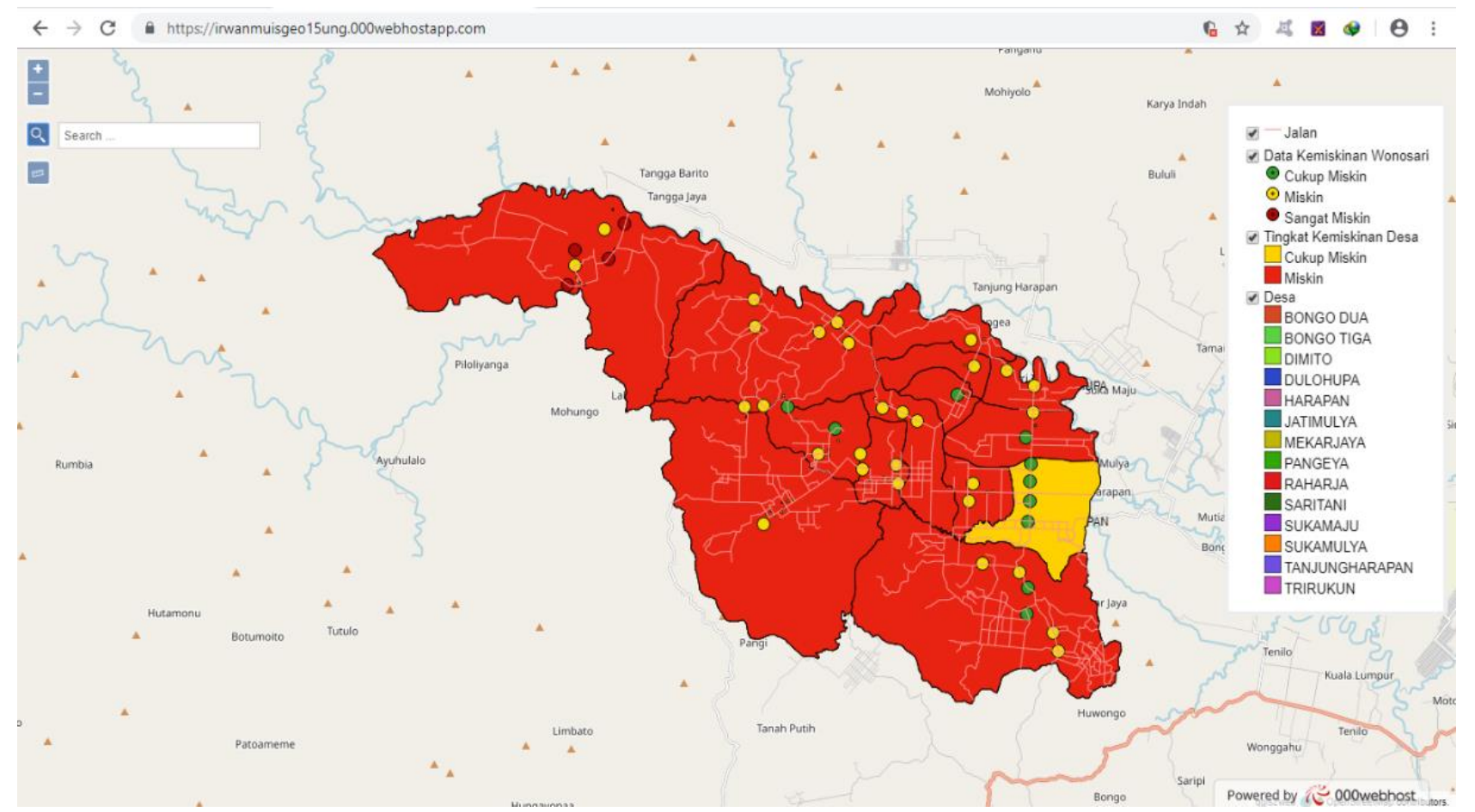

Figure 6. The results of webGIS hosting

open to the internet window. However, the charactrictics of the map is still localhost, which means that only users can view and access the map data.

Thus a media or server is needed that is able to store and manage data so that it can be displayed and accessed by all parties using any network system. The process of integration of poverty level maps and distribution of poor households is carried out on 000.webhostapp.com hosting media with the url address https://irwanmuisgeo15ung.000webhostapp.com this hosting media is free and has good connectivity in accessing webgis, with a display that can be supported on various types of PCs, laptops and android. The results of webgis integration are presented in Figure 6.

\section{Conclusion}

Web-based Geographic Information System, provides an overview of poverty levels and shows the distribution of households that have geographic references, so that data related to household poverty levels can be easily and efficiently seen and accessed by all parties. Research using 304 households as a sample illustrates the condition of the poverty level of the Wonosari Subdistrict household with a percentage of $14 \%$ in the quite poor class, $72 \%$ of the households in the poor class and $14 \%$ of the households in the very poor class spread across all village area in Wonosari District.

\section{Acknowledgments}

The author would like to thank the Boalemo Regency government for giving consent to research the Wonosari Subdis trict area. A big thank to my mentors and Mr. Rahmat Jaya Lahay, S.Si, M.Sc, for his contribution and assistance in the process of building webGIS, and thanks to the management of the Geography Laboratory for lending tools needed in this research.

\section{References}

Bank Dunia. (2015). the poverty rate varies greatly among the top 10 countries largest number of poor. pada 18 Januari 2018, https://economy.okezone.com/read/2015/10/06/20/1227140/indonesiatermiskin-kesembilan-10-penduduk-dunia-terancam-melarat.

BPS (2018, November 18). Analisis dan Perhitungan Tingkat Kemiskinan.Badan Pusat Statistik Kabupaten Boalemo: www.bps.go.id

Dimitra, S., \& Yuliastuti, N. (2012). Potensi Kampung Nelayan Sebagai Modal Permukiman Berkelanjutan Di Tambaklorok, Kelurahan Tanjung Mas. Jurnal Teknik PWK (Perencanaan Wilayah Kota), 1(1), 11-18. Diambil dari http://ejournal-s1.undip.ac.id/index.php/pwk 
Dinas Sosial. (2018, Mei 22). Keluarga Penerima Manfaat Beras Sejahtera (RASTRA). Intreview: Kepala Dinas Sosial Kabupaten Boalemo.

Fithriyyah, U., Akbar, F., \& Suryamen, H. (2016). Pembangunan Sistem Informasi Sebaran Rumah Tangga Miskin Kelurahan Puhun Tembok Bukittinggi. Jurnal Sisfo, 06 (01), 89-104. https://doi.org/10.24089/j.sisfo.2016.09.007.

Gibranda, G., Ramdani, F., \& Aknuranda, I. (2017). Pengembangan WebGIS Untuk Analisis Dan Pemodelan Data Menggunakan Teknik Regresi Spasial Dan R-Shiny Web Framework (Studi Kasus: Data Kemiskinan dan Zakat Jawa Timur). Jurnal Pengembangan Teknologi Informasi Dan Ilmu Komputer, 2(3), 1290-1298. Diambil dari http://j-ptiik.ub.ac.id/index.php/jptiik/article/view/1132

Harmes, H., Juanda, B., Rustiadi, E., \& Barus, B. (2017). Pemetaan Efek Spasial pada Data Kemiskinan Kota Bengkulu. Journal of Regional and Rural Development Planning, 1(2), 192201. https://doi.org/10.29244/jp2wd.2017.1.2.192-201

Lee, J., \& Wong, D. W. S. (2001).Statistical analysis with ArcView GIS. UK: Wiley. 